\title{
Effects of thermal processing on fatty acids, phytosterols and other chemical properties of black table olives
}

\author{
Efeitos do processamento térmico sobre ácidos graxos, fitoesteróis e outras propriedades \\ químicas de azeitonas pretas de mesa
}

\author{
M. Dias-Martins ${ }^{1}$; L. P. Cappato ${ }^{2}$; F. M. Trombete ${ }^{3 *}$; T. L. Silva ${ }^{1}$; O. D. Gamallo ${ }^{1}$; \\ L. M. Keller ${ }^{1}$; I. M. Augusta ${ }^{1}$; T. Saldanha ${ }^{1}$ \\ ${ }^{I}$ Department of Food Technology/Institute of Technology/Federal Rural University of Rio de Janeiro, 23890-000, \\ Seropédica-RJ, Brazil \\ ${ }^{2}$ Federal Institute Gioano, Campus Rio Verde, Rodovia Sul Goiana, Km 01, Zona Rural, 75901-970, Rio Verde-GO, \\ Brazil \\ ${ }^{3}$ Department of Food Engineering/Federal University of São João del-Rei, Campus Sete Lagoas, 35701-970, Sete \\ Lagoas-MG, Brazil
}

*trombete@ufsj.edu.br

(Recebido 21 de março de 2020; aceito 21 de dezembro de 2020)

\begin{abstract}
Black table olives are a popular food and highly appreciated for its taste, typically used in pizzas, salads and other meals. Among the compounds present in this food are the bioactive lipids like monounsaturated fatty acids (MUFAs) and phytosterols, related to the prevention of the occurrence of some chronic diseases. Pasteurization may be applied to black table olives aiming to ensure its microbiological quality, but this processing can cause undesired degradation of thermosensitive organic compounds. This work aimed to evaluate the changes that occur in chemical properties, fatty acids profile, and phytosterols in Azapa black table olives after pasteurization. The olives were treated at $80^{\circ} \mathrm{C}$ for $5 \mathrm{~min}$, which achieved a lethality factor $\mathrm{F}_{62.4^{\circ} \mathrm{C}}$ equal $40 \mathrm{~min}$. Fatty acids and phytosterols determination were carried out using a Gas Chromatography with Flame Ionization Detector (GC-FID). Other components were analyzed by physicochemical determinations. The results demonstrate that Azapa black table olives are a source of unsaturated fatty acids $\left(72.33 \mathrm{~g} \cdot 100^{-1} \mathrm{~g}\right)$ and total phytosterols $\left(137.4 \mathrm{mg} \cdot 100^{-1} \mathrm{~g}\right)$, substances associated with beneficial health effects. Pasteurization did not promote chemical changes $(\mathrm{p}>0.05)$ in total protein, lipids, ash content, acidity, $\mathrm{pH}$, and total chlorides in the samples, except for moisture content that had $4.1 \%$ of reduction. The fatty acid composition also was not affected $(\mathrm{p}>0,05)$. However, phytosterol levels were affected $(\mathrm{p}<0.05)$ by thermal processing, with a decrease of about $24.6 \%$ of campesterol, $16.8 \%$ of $\beta$-sitosterol, and $60.9 \%$ of stigmasterol. Data suggest that thermal processing used to treat Azapa black olives must be optimized to minimize this negative effect.

Keywords: thermal processing, plant sterols, stigmasterol
\end{abstract}

Azeitonas pretas de mesa são populares e muito apreciadas pelo sabor, tipicamente usadas em pizzas, saladas e outras refeições. Dentre os compostos presentes nesse alimento estão os lipídios bioativos tais como os ácidos graxos monoinsaturados (AGMI) e os fitoesteróis, relacionados com a prevenção da ocorrência de determinadas doenças crônicas. A pasteurização pode ser aplicada nas azeitonas de mesa com objetivo de garantir a qualidade microbiológica, porém, esse processamento pode causar degradações indesejadas em compostos orgânicos termossensíveis. Esse trabalho objetivou avaliar as alterações que ocorrem nas propriedades químicas, perfil de ácidos graxos e níveis de fitoesteróis presentes em azeitonas pretas de mesa da variedade Azapa após pasteurização. As azeitonas foram tratadas a $80{ }^{\circ} \mathrm{C}$ por 5 min, atingindo um fator

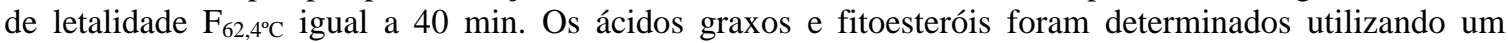
cromatógrafo gasoso com detector de ionização por chama (GC-FID). Os demais compostos foram mensurados por análises físico-químicas. Os resultados demonstraram que as azeitonas avaliadas são fonte de ácidos graxos insaturados $\left(72,33 \mathrm{~g} \cdot 100^{-1} \mathrm{~g}\right)$ e de fitoesteróis $\left(137,4 \mathrm{mg} \cdot 100^{-1 \mathrm{~g}}\right)$, substâncias associadas com efeitos benéficos a saúde. A pasteurização não promoveu alterações ( $>0.05)$ nos níveis de proteínas totais, lipídios, cinzas, acidez, $\mathrm{pH}$ e cloretos totais, exceto pelo teor de umidade que teve redução de $4,1 \%$. A composição dos ácidos graxos também não foi afetada ( $\mathrm{p}>0,05)$. No entanto, os níveis de fitoesteróis foram alterados $(\mathrm{p}<0.05)$ pelo tratamento térmico, com diminuição de $24,6 \%$ no campesterol, $16,8 \%$ no $\beta$-sitosterol e de $60,9 \%$ no estigmasterol. Os resultados sugerem que o tratamento térmico usado para as azeitonas pretas de mesa da variedade Azapa devem ser otimizados a fim de minimizar tais efeitos negativos. Palavras-chave: processamento térmico, esteróis vegetais, estigmasterol 


\section{INTRODUCTION}

The consumption of olives in natura is not recommended due to the presence of a glycoside called oleuropein, responsible for its bitter taste [1]. According to the International Council of Olive Oil (IOC) the olive table is defined as the product prepared from the healthy olive fruit, subjected to treatment to eliminate the natural bitterness present in the fruit and preserved by natural fermentation or heat treatment, with or without chemical preservatives, bottled with or without topping liquid [2].

Different varieties of olive trees have been cultivated in South America. This food is currently an important export product, especially in countries like Argentina and Chile [3]. In Azapa Valley, in Chile, are produced the Azapa olives, the most popular Chilean cultivar for black table olives processing, which is produced from ripe fruits, fermented and preserved by the process of pasteurization and added of chemical preservatives, such as benzoate and sorbate, or by the combination of both techniques [4].

According to the "Commercial Standard Applicable to Olive Tables [2], the pasteurization applied to black table olives must achieve a lethality factor $(F)$ of $15 \mathrm{~min}$ in a temperature equal to $62.4^{\circ} \mathrm{C}$. This value refers to propionic bacteria as the reference microorganism, characterized by a $\mathrm{z}$-value of $5.25^{\circ} \mathrm{C}$ [5]. In this process, precise design and monitoring are essential to establish adequate time and temperature to not promote deterioration of the olives or cause undesired degradation of thermosensitive organic compounds [5,6].

Among the bioactive compounds founds in olives are the monounsaturated fatty acids (MUFAs). The primary fatty acid in this group is the oleic acid (C18:1), constituting about $65 \%$ of the total fatty acids composition of olives, and the linoleic (C18:2) and linolenic acid (C18:3), corresponding together with approximately $8 \%$ of these [7, 8]. Due to the higher levels of MUFAs, especially C18:1, and lower levels in saturated fatty acids, olive oils are considered very healthy due to the know beneficial effect of MUFAs on preventing chronic inflammation and liver and heart diseases $[9,10]$.

The plant sterols, or phytosterols, such as sitosterol and stigmasterol, are also bioactive components present in olives. Dietary intake of phytosterols has been demonstrated to be inversely related to low-density lipoprotein (LDL) cholesterol and serum total cholesterol levels [11]. However, when present in foods that are submitted to thermal processing, phytosterols may be partially degraded [12].

It is well known that heat treatments used to ensure food quality may also negatively affect food quality. In this way, this work aimed to evaluate the changes that occur in chemical composition, fatty acids profile, and phytosterols content of Azapa black table olives after the pasteurization treatment applied to the fruits.

\section{MATERIALS AND METHODS}

\subsection{Olive samples}

Black table olives of the Azapa variety imported from Chile were purchased from a food industry located in the city of Rio de Janeiro, Brazil. A sample of $10 \mathrm{Kg}$ was collected from a bag containing $50 \mathrm{Kg}$ of the product. The olives were washed and $300 \mathrm{~g}$ (about 40 olives) were added in sterilized glass jars. Three jars were filled with brine at $45^{\circ} \mathrm{C}$, composed by water, salt, and lactic acid (97.5: 2: $0.5, \mathrm{v} / \mathrm{w} / \mathrm{v}$, respectively) and then subjected to the heat treatment. The other three jars prepared in the same way but not subjected to heat treatment was used as control.

\subsection{Thermal processing}

The jars containing olives in brine were subjected to exhaust tunnel for $25 \mathrm{~s}$ and then tapped and inverted to provide the contact of the cover with the brine. The jars were placed in a stainless steel perforated basket and pasteurized at $80^{\circ} \mathrm{C}$ for $5 \mathrm{~min}$. The temperature and time used in the thermal treatment were selected based on the conditions used by Brazilian industries that process table 
olives. The control of the process was performed by E-Val Flex Module (Ellab A/S, Hilleroed, Denmark), using thermocouples of $1 \mathrm{~mm}$, inserted in the jars, recording the temperature along the process, every $8 \mathrm{~s}$. After 5 min of processing, the jars were cooled in an ice bath.

\subsection{Physicochemical analysis}

The samples were ground and homogenized in a multiprocessor (Mega Master, RI 3170, Sao Paulo, Brazil) to obtain a homogeneous dough. Physicochemical analysis were performed according to the methodologies recommended by AOAC [13]. Total protein content $\left(\mathrm{g} \cdot 100^{-1} \mathrm{~g}\right)$ was determined by Soxhlet method, ash content $\left(\mathrm{g} \cdot 100^{-1} \mathrm{~g}\right)$ by gravimetric determination (incineration at $\left.550^{\circ} \mathrm{C}\right)$, lipids content $\left(\mathrm{g} \cdot 100^{-1} \mathrm{~g}\right)$ by Bligh and Dyer method, total chloride $\left(\mathrm{g} \cdot 100^{-1} \mathrm{~g}\right)$ and total acidity (\% of lactic acid) by titration method, moisture content (\%) by oven-drying at $105{ }^{\circ} \mathrm{C}$ and $\mathrm{pH}$. Solvents and reagents were analytical grades purchased from Vetec (Sao Paulo, SP, Brazil).

\subsection{Fatty acids determination}

Total lipids extracted were kept in a chloroform/methanol $(9: 1, \mathrm{v} / \mathrm{v})$ with $t$-Butyl-hydroquinone solution to prevent oxidation. $1 \mathrm{~mL}$ of lipid solution were transferred to a glass vial and evaporated to dryness. Then, ${ }_{-} \mathrm{mL}$ of $7 \% \mathrm{BF}_{3}$ solution and $\_\mathrm{mL}$ of toluene were added. The glass vial was sealed and heat at $100{ }^{\circ} \mathrm{C}$ by _ minutes. Then the tube was cooled to room temperature and $5 \mathrm{~mL}$ of water, $1 \mathrm{~mL}$ of hexane and $1 \mathrm{~g}$ of sodium sulfate were added with subsequent stirring. After layers separation, the top layer was transferred to another vial containing $1 \mathrm{~g}$ of sodium sulfate, stirred and the liquid was transferred to a vial to GC analysis

Total lipids extracted were dissolved in chloroform/methanol $(9: 1, \mathrm{v} / \mathrm{v})$ and $t$-Butylhydroquinone was added to prevent oxidation. The samples $(25 \mathrm{mg})$ were converted into methyl esters by transesterification, according to Huang, Wang and Crenshaw (2006) [14].

The fatty acids were determined as described in Silva et al. (2019) [15] using a gas chromatograph (Shimadzu GC 2010, Tokyo, Japan), equipped with a split injector (1:50), a flame ionization detector, and a workstation. The chromatographic separation was performed in a fused silica CP-SIL 88 capillary column $100 \mathrm{~m} \times 0.25 \mathrm{~mm}$ i.d., with $0.20 \mu \mathrm{m}$ film thickness (Chrompack, Middelburg, The Netherlands). The chromatographic conditions were: initial temperature equal $100{ }^{\circ} \mathrm{C}(5 \mathrm{~min})$ followed by $5{ }^{\circ} \mathrm{C} / \mathrm{min}$ up to $160{ }^{\circ} \mathrm{C}$ (zero $\left.\mathrm{min}\right), 8^{\circ} \mathrm{C} / \mathrm{min}$ up to $230{ }^{\circ} \mathrm{C}(12 \mathrm{~min})$; injector and detector temperatures were $250^{\circ} \mathrm{C}$ and $280^{\circ} \mathrm{C}$, respectively. The equipment used hydrogen as the carrier gas at a flow rate of $1 \mathrm{~mL} / \mathrm{min}$. In order to identify the chromatographic peaks of the sample, the retention times of FAME standards were used, and the quantification was performed by internal standardization, with undecanoic methyl ester as the internal standard. The results were calculated in $\mathrm{mg}$ per $100 \mathrm{~g}$ of lipids. Factors for the conversion of fatty acids methyl esters into their corresponding triglycerides were utilized [16].

\subsection{Phytosterols}

Phytosterols were obtained with saponification of the samples $(1 \mathrm{~g}$ of sample, $4 \mathrm{~mL}$ of a $50 \%$ ethanol solution of $\mathrm{KOH}$ and $6 \mathrm{~mL}$ of ethanol) at $20^{\circ} \mathrm{C}$ for $22 \mathrm{~h}$ in the dark and the unsaponifiable matter was extract 4 times with hexane, as described in Silva et al. (2019) [15]. The samples and standards were derivatized to trimethylsilyl (TMS) ethers. The TMS derivates were diluted with 1 $\mathrm{mL}$ of hexane, filtered through a $22 \mu \mathrm{m}$ filter (Millipore, Maryland, MD, USA), and injected into a gas chromatograph (Shimadzu GC 2010, Tokyo, Japan), equipped with a split injector (1:20), a flame ionization detector, and a workstation. The TMS-ether derivates of sterols were separated in a capillary column Rtx-5-MS (30m x $0.25 \mathrm{~mm}$ x $0.25 \mu \mathrm{m}$, Restek, Bellefonte, USA). The oven program was: initial temperature, $230{ }^{\circ} \mathrm{C}(0 \mathrm{~min})$; a heating rate of $2{ }^{\circ} \mathrm{C} / \mathrm{min}$ to a temperature of $264{ }^{\circ} \mathrm{C}(5 \mathrm{~min})$; and then a heating rate of $1{ }^{\circ} \mathrm{C} / \mathrm{min}$ to a final temperature of $275^{\circ} \mathrm{C}(2 \mathrm{~min})$. The injector temperature was $290{ }^{\circ} \mathrm{C}$ and detector $350{ }^{\circ} \mathrm{C}$. The carrier gas was hydrogen at a flow rate of $1 \mathrm{~mL} / \mathrm{min}$. Identification was done by comparison with the retention times of phytosterols 
standards. Quantification was done by external standardization with concentrations ranging from 0.05 to $1.0 \mathrm{mg} / \mathrm{mL}$.

\subsection{Data analysis}

Statistical analyses were performed using Origin® ${ }^{\circledR}$ 6.0. A probability value of 0.05 was used to determine the statistical significance in ANOVA and Duncan tests. All measurements were performed in triplicate and results are shown as means \pm standard deviation.

\section{RESULTS AND DISCUSSION}

The $\mathrm{F}$ value in a thermal process is defined as the equivalent processing time of a hypothetical thermal process, at a constant temperature, that eliminates a given percentage of microorganisms as the actual thermal process [16]. The International Olive Council recommend an $\mathrm{F} 62.4^{\circ} \mathrm{C}$ to the pasteurization of table olives corresponding to $15 \mathrm{~min}$ [2]. In the present study, using the same conditions of the heat processing mostly used by Brazilian food industries that process table olives $\left(80^{\circ} \mathrm{C} / 5 \mathrm{~min}\right.$ ), was achieved a $\mathrm{F} 62.4^{\circ} \mathrm{C}$ equal $40 \mathrm{~min}$, which is higher than the minimum necessary to ensure the microbiological quality of the product. Figure 1 shows the data obtained during pasteurization.

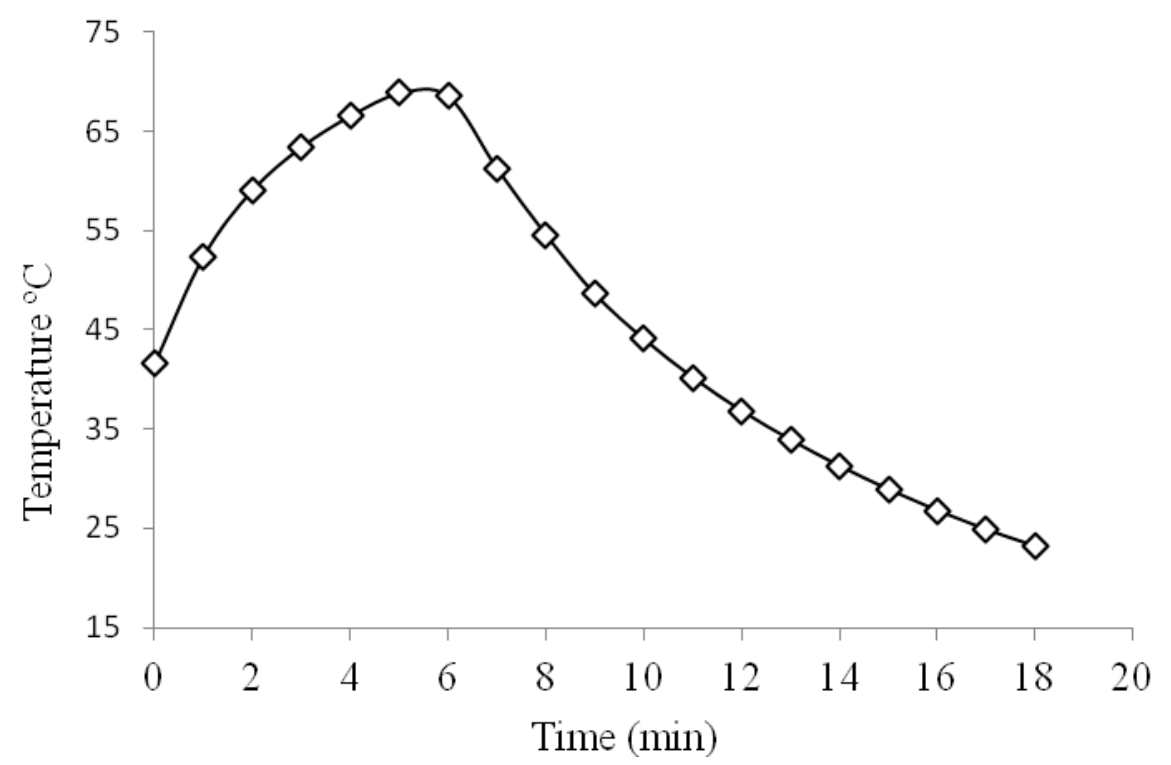

Figure 1: Data obtained during pasteurization $\left(80^{\circ} \mathrm{C}\right.$ during $\left.5 \mathrm{~min}\right)$ of black table olives.

After heat processing, no chemical changes $(\mathrm{p}>0.05)$ in total protein, lipids, ash content, acidity, $\mathrm{pH}$, or total chlorides were observed, except for moisture content that decreased $4.1 \%$. According to Gómez, García and Navarro (2006) [17], when a temperature of $80^{\circ} \mathrm{C}$ is used for pasteurization, the general quality of the olives remains practically unaltered. Table 1 shows the results of the chemical analysis.

The moisture content for the different samples ranged from $62.3 \%$ to $67.2 \%$ and was lower $(\mathrm{p}<0.05)$ in pasteurized olives, which can be explained by the heating process that favors the loss of water to the brine. The thermal process did not promote significant changes ( $p>0.05)$ on fatty acid composition (g. $100 \mathrm{~g}^{-1}$ d.b.), as can be seen in Table 2 . 
Table 1: Effects of pasteurization $\left(80^{\circ} \mathrm{C}\right.$ during $5 \mathrm{~min}$ ) on physicochemical characteristics of black table olives.

\begin{tabular}{ccc}
\hline Parameters & \multicolumn{2}{c}{ Black table olives } \\
Unpasteurized & Pasteurized \\
\hline Moisture $\left(\mathrm{g} .100^{-1} \mathrm{~g}\right)$ & $67.2 \pm 0.3^{\mathrm{a}}$ & $63.1 \pm 0.3^{\mathrm{b}}$ \\
Ash content $\left(\mathrm{g} \cdot 100^{-1} \mathrm{~g}\right)$ & $7.9 \pm 0.4^{\mathrm{a}}$ & $8.2 \pm 0.3^{\mathrm{a}}$ \\
Protein content $\left(\mathrm{g} .100^{-1} \mathrm{~g}\right)$ & $1.43 \pm 0.06^{\mathrm{a}}$ & $1.47 \pm 0.09^{\mathrm{a}}$ \\
Total lipids $\left(\mathrm{g} .100^{-1} \mathrm{~g}\right)$ & $22.8 \pm 2.8^{\mathrm{a}}$ & $20.0 \pm 2.7^{\mathrm{a}}$ \\
Total acidity $(\%$ of acid lactic) & $0.78 \pm 0.01^{\mathrm{a}}$ & $0.79 \pm 0.02^{\mathrm{a}}$ \\
pH & $3.8 \pm 0.1^{\mathrm{a}}$ & $3.8 \pm 0.1^{\mathrm{a}}$ \\
Total chlorides $\left(\mathrm{g} \cdot 100^{-1} \mathrm{~g}\right)$ & $0.12 \pm 0.02^{\mathrm{a}}$ & $0.13 \pm 0.01^{\mathrm{a}}$ \\
\hline
\end{tabular}

Means followed by the same letter in the line are not different $(\mathrm{P}>0.05)$ by Duncan test.

The major saturated fatty acid (SFA) $\left(\mathrm{g} .100 \mathrm{~g}^{-1}\right)$ was palmitic acid (C16:0), followed by stearic acid (C18:0) in both control and pasteurized samples. Monounsaturated fatty acids (MUFA) correspond to the principal fatty acids present in Azapa black table olives, with the predominance of oleic acid (18:1 $\omega$-9cis), followed by palmitoleic acid (16:1 $\omega-7)$ and eicosenoic acid (20:1 $\omega-$ 11). Linolenic acid (18:2 $\omega-6$ cis) was the polyunsaturated fatty acid found in high levels, followed by arachidonic acid (20:4 $\omega-6)$.

Table 2: Effects of thermal processing in fatty acids composition of black table olives $\left(\mathrm{g}^{1} 100 \mathrm{~g}^{-1}\right.$ of samples in dry basis).

\begin{tabular}{lll}
\hline Fatty acids & \multicolumn{2}{c}{ Samples } \\
Not pasteurized & Pasteurized \\
\hline C16:0 $18: 0$ & $19.7 \pm 0.3^{\mathrm{a}}$ & $19.6 \pm 0.1^{\mathrm{a}}$ \\
C $20: 0$ & $3.0 \pm 0.1^{\mathrm{a}}$ & $3.0 \pm 0.1^{\mathrm{a}}$ \\
Total saturated & $0.5 \pm 0.1^{\mathrm{b}}$ & $0.5 \pm 0.1^{\mathrm{a}}$ \\
C16:1 $\omega^{-9}$ cis & $23.2 \pm 0.3^{\mathrm{a}}$ & $23.4 \pm 0.1 \mathrm{a}$ \\
C17:1 $\omega^{-7}$ cis & $2.4 \pm 0.1^{\mathrm{b}}$ & $2.6 \pm 0.2^{\mathrm{a}}$ \\
C18:1 $\omega^{-9}$ tr & $0.1 \pm 0.01^{\mathrm{b}}$ & $0.1 \pm 0.01^{\mathrm{a}}$ \\
C18:1 $\omega^{-9}$ cis & $0.0 \pm 0.0^{\mathrm{a}}$ & $0.01 \pm 0.1^{\mathrm{a}}$ \\
$20: 1 \omega^{-11}$ cis & $47.0 \pm 1.0^{\mathrm{a}}$ & $48.0 \pm 0.2^{\mathrm{a}}$ \\
Total monounsaturated & $0.9 \pm 0.1^{\mathrm{b}}$ & $0.9 \pm 0.1^{\mathrm{a}}$ \\
$18: 2 \omega^{-6}$ cis & $50.4 \pm 0.9^{\mathrm{a}}$ & $51.2 \pm 0.1^{\mathrm{a}}$ \\
C18:3 $\omega^{-3}$ cis & $21.4 \pm 0.5^{\mathrm{a}}$ & $20.5 \pm 0.1^{\mathrm{a}}$ \\
C20:2 $\omega^{-6}$ cis & $0.02 \pm 0.01^{\mathrm{a}}$ & $0.01 \pm 0.01^{\mathrm{a}}$ \\
C20:4 $\omega^{-6}$ cis & $0.12 \pm 0.1^{\mathrm{a}}$ & $0.15 \pm 0.1^{\mathrm{a}}$ \\
C20:5 $\omega^{-3}$ cis & $0.18 \pm 0.04^{\mathrm{a}}$ & $0.32 \pm 0.02^{\mathrm{a}}$ \\
C22:6 $\omega^{-3}$ cis & $0.05 \pm 0.0^{\mathrm{a}}$ & $0.06 \pm 0.01^{\mathrm{a}}$ \\
Total polyunsaturated & $0.09 \pm 0.0^{\mathrm{a}}$ & $0.10 \pm 0.01^{\mathrm{a}}$ \\
Total unsaturated & $21.87 \pm 0.5^{\mathrm{a}}$ & $21.09 \pm 0.2^{\mathrm{a}}$ \\
TFA & $72.29 \pm 0.4^{\mathrm{a}}$ & $72.33 \pm 0.3^{\mathrm{a}}$ \\
\hline
\end{tabular}

Means followed by different letters in the line are different $(\mathrm{p}<0.05)$ by Dunkan test

According to the data observed, pasteurization did not cause variations in the fatty acid composition of Azapa black table olives. In contrast, Bešter et al. (2008) [18] and Souza et al. 
(2004) [19] described that for olive oils the unsaturated fatty acids are susceptible to thermal degradation when subjected to high temperatures and, this thermal degradation occurred first in the PUFAs, followed by monounsaturated and saturated fatty acids, fact that was not observed in the present research when olives were pasteurized.

Results showed that total phytosterols levels of black table olives are reduced $(\mathrm{p}<0,05)$ after pasteurization, with decreases equivalent of $24,62 \%$ for campesterol, $16,84 \%$ for $\beta$-sitosterol and $60,95 \%$ for stigmasterol, and all samples differed from control, as presented in Table 3. Even with reduced levels, phytosterol content in black table olives can be considered a source of such compounds.

Table 3: Effects of thermal processing in phytosterols levels of black table olives (mg.100 ${ }^{-1 g}$ d.b.).

\begin{tabular}{ccc}
\hline Phytosterols & $\begin{array}{c}\text { Olives not pasteurized } \\
\left(\mathbf{m g . 1 0 0 g ^ { - 1 }}\right)\end{array}$ & $\begin{array}{c}\text { Pasteurized olives* } \\
\left(\mathbf{m g . 1 0 0 g}^{\mathbf{1}}\right)\end{array}$ \\
\hline Campesterol & $6.5 \pm 1,59^{\mathrm{a}}$ & $4.9 \pm 0,36^{\mathrm{b}}$ \\
$\beta$-Sitosterol & $151.32 \pm 42,72^{\mathrm{a}}$ & $125.9 \pm 8,23^{\mathrm{b}}$ \\
Stigmasterol & $16.9 \pm 2,72^{\mathrm{a}}$ & $6.6 \pm 0,61^{\mathrm{b}}$ \\
Total & $174.7^{\mathrm{a}}$ & $137.4^{\mathrm{b}}$ \\
\hline
\end{tabular}

Means followed by different letters in the line are different $(\mathrm{p}<0.05)$ by Fisher test

According to Rudzińska, Przybylski and Erwin (2009) [20], thermal degradation of phytosterols occurs from $60{ }^{\circ} \mathrm{C}$, increasing with the increase of temperature, with the formation of oxidized phytosterols, fragmented phytosterol molecules, volatile compounds, and oligomers. Some of these components formed are responsible for off-flavor in foods. Soupas et al. (2004) [21] demonstrated in a study using model systems, composed by tripalmitin and purified rapeseed oil, that about $20 \%$ of stigmasterol is oxidized when subjected to oven drying at high temperatures, with consequent formation of oxidation products.

In simulated heat treatments, using milk enriched with phytosterols and subjected to different systems (electrical heating, microwave and oven), thermal degradation of stigmasterol and others phytosterols was also reported. The mainly mechanism for this degradation is known to be the oxidation process, affecting phytosterols at a similar intensity as cholesterol [22].

\section{CONCLUSION}

According to the results, the pasteurization process used did not significantly affect the chemical composition and fatty acid profile of black olives. However, a significant variation in the composition of phytosterols was observed, compromising the nutritional value of this food. In this way, the thematic treatment must be optimized so that this negative effect is minimized.

\section{ACKNOWLEDGMENTS}

The authors would like to thank the company Masgovi (Rio de Janeiro, Brazil), for donating the olive samples, the SENAI (National Service of Industrial Training) located in Vassouras, Brazil, for the support in conducting the heat treatment used in the research and, also, the Coordination of Superior Level Staff Improvement (CAPES) for financial support (Pro-equipamentos/2011) for acquisition of the GC-FID equipment.

\section{REFERENCES}

1. Arroyo-López F, Bautista-Gallego J, Rodríguez-Gómez F, Garrido-Fernández A, Mendez-Vilas A. Predictive microbiology and table olives. In: Méndez-Vilas A, editor. Current research, technology and education topics in applied microbiology and microbial biotechnology. Badajoz: Formatex Research Center; 2010. p. 1452-1461. 
2. International Olive Council. Trade Standard Applying to Table Olives; 2004 [cited 2021 Oct 13]. Available from: http://www.internationaloliveoil.org/.2004.

3. Embrapa Clima Temperado. Cultivo de oliveira (Olea europaea L.) mercados e comercialização; 2011 [cited 2021 oct 13]. Available from: https://www.infoteca.cnptia.embrapa.br/

4. Cappato LP, Ferreira EHDR, Rosenthal A. Table olives in Brazil: market, technology and legal aspects. Cienc Rural. 2015;45(7):1327-35, doi: 10.1590/0103-8478cr20140879.

5. Dimou AE, Panagou NGS, Yanniotis S. Analysis of thermal processing of table olives using computational fluid dynamics. J Food Sci. 2013;78(11):E1695-703, doi:10.1111/1750-3841.12277.

6. Argyri A, Efstathios ZP, George-John EN, Chrysoula CT. Nonthermal pasteurization of fermented green table olives by means of high hydrostatic pressure processing. Biomed Res Int. 2014;2014:[9 p.], doi:10.1155/2014/515623.

7. Boskou D, Blekas G, Tsimidou M. Olive oil composition. In: Boskou D, editor. Olive oil: Chemistry and technology. Champaign: American Oil Chemists' Society Press; 2006. p. 1-33.

8. Ghanbari R, Farooq A, Khalid MA, Anwarul-Hassan G, Nazamid S. Valuable nutrients and functional bioactives in different parts of olive (Olea Europaea L.) - a review. Int J Mol Sci. 2012;13(3):3291-340, doi:10.3390/ijms13033291.

9. Nigam P, Bhatt S, Misra A, Chadha DS, Vaidya M, Dasgupta J, Pasha QMA. Effect of a 6-month intervention with cooking oils containing a high concentration of monounsaturated fatty acids (olive and canola oils) compared with control oil in male asian indians with nonalcoholic fatty liver disease. Diabetes Technol Ther. 2014;16(4):255-61, doi:10.1089/dia.2013.0178.

10. Virtanen JK, Mursu J, Tuomainen JP, Voutilainen S. Dietary fatty acids and risk of coronary heart disease in men: the Kuopio Ischemic Heart Disease Risk Factor Study. Arterioscler Thromb Vasc Biol. 2014;34(12):2679-87, doi:10.1161/ATVBAHA.114.304082.

11. Lin X, Racette SB, Lefevre M, Spearie CA, Most M, MAL, Ostlund RE. The effects of phytosterols present in natural food matrices on cholesterol metabolism and LDL-cholesterol: a controlled feeding trial. Eur J Clin Nutr. 2010; 64(12):1481-7, doi:10.1038/ejen.2010.180.

12. Berasategi I, Blanca B, Diana A, Astiasarán I. Stability of avocado oil during heating: Comparative study to olive oil. Food Chem. 2012;132(1):439-46, doi:10.1016/j.foodchem.2011.11.018.

13. Association Of Official Analytical Chemistry (AOAC). 2010. Official methods of analysis of the Association of Official Analytical Chemistry. 18. ed. Washington: Arlington. 1115 p.

14. Huang Z, Wang B, Crenshaw AA. A Simple method for the analysis of trans fatty acid with GC-MS and AT $^{\text {TM}}$-Silar-90 capillary column. Food Chem. 2006;98(4):593-98, doi:10.1016/j.foodchem.2005.05.013.

15. Silva TL., Oliveira VS, Augusta IM, Keller LM, Gamallo OD, Saldanha T. Aroeira (Schinus terebinthifolius Raddi) Fruit: Chemical Composition and Antioxidant Capacity. Rev Virtual Quim. 2019;11(5):1614-1624, doi: 10.21577/1984-6835.20190113.

16. Stoforos VT. Thermal Processing. In: Varzakas T, Tzia C, editors. Handbook of food processing: food preservation. London: CRC Press; 2015. p. 37-54.

17. Gómez AHS, García PG, Navarro LR. Elaboration of table olives. Grasas Aceites. 2006;57(1):86-94, doi: 10.3989/gya.2006.v57.i1.24.

18. Bešter E, Butinar B, Bučar-Miklavčič M, Golob T. Chemical changes in extra virgin olive oils from Slovenian Istra after thermal treatment. Food Chem. 2008;108(2):446-54, doi:10.1016/j.foodchem.2007.10.061.

19. Souza AG, Santos JCO, Conceição MM, Silva MC, Prasad S. A thermoanalytic and kinetic study of sunflower oil. Braz J Chem Eng. 2004;21(2):265-73, doi: 10.1590/S0104-66322004000200017.

20. Rudzińska M, Przybylski R, Erwin W. Products formed during thermo-oxidative degradation of phytosterols. J Am Oil Chem Soc. 2009;86(7):651-62, doi:10.1007/s11746-009-1397-0.

21. Soupas L, Juntunen L, Lampi AM, Piironen V. Effects of sterol structure, temperature, and lipid medium on phytosterol oxidation. J Agric Food Chem. 2004;52(21):6485-91, doi:10.1021/jf049168k.

22. Menéndez-Carreño M, Ansorena D, Astiasarán I. Stability of sterols in phytosterol-enriched milk under different heating conditions. J Agric Food Chem. 2008;56(21):9997-10002, doi:10.1021/jf802000m. 